\title{
INTRODUCTION TO WALT WHITMAN'S "MANLY HEALTH AND TRAINING"
}

\section{ZACHARY TURPIN}

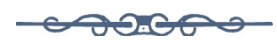

NotwithSTANDING NEARLY EVERYTHING he ever said in poetry, Walt Whitman could be surprisingly anxious about his own disappearance. "Some day I'll die," he reminded his friend and literary executor Horace Traubel, "maybe surprise you all by a sudden disappearance: then where'll my book be? That's the one thing that excites me: most authors have the same dread-the dread that something or other essential that they have written may somehow become side-tracked, lost-lost forever." As it turned out, much of his writing was indeed lost, despite his talent for self-bibliography and the efforts of generations of scholars to sort through Whitman's mountains of personal papers. He simply wrote too much. Some of his texts were bound to sink from sight-with Whitman occasionally trying to scuttle them himself, anxieties be damned. His early short stories, for example, embarrassed him dreadfully: "My serious wish," he confessed in Specimen Days and Collect (1882), "were to have all those crude and boyish pieces quietly dropp'd in oblivion." In the end, Whitman collected a few of them merely "to avoid the annoyance of their surreptitious issue." 2 Other early writings were less persistently annoying, and thus less fortunate. Whitman's mid-life journalism and freelance writings were particularly unfortunate in this regard. Published shortly after the inception of Leaves of Grass (from 1855 to 1860 or so), usually anonymously or under pen names, much of this work fell into almost total obscurity immediately after the poet's "sudden disappearance." It has so far required more than a century and a half of work, with Whitman's own encouragement- "Missing me one place search another"- to recover his mid-life prose publications. ${ }^{3}$ The earliest such "find" of which I am aware is Whitman's anonymous "New York Dissected" series (1856). It was forgotten for eighty years in the pages of Fowler and Wells' Life Illustrated magazine until Emory Holloway and Ralph 
Adimari uncovered it in $1936 .{ }^{4}$ Another notable discovery was Whitman's "Paumanok" correspondence, a wide-ranging trio of letters to the editor of the Washington, D.C., National Era (1850), finally republished by Rollo G. Silver in 1948. ${ }^{5}$ Then there is the complete series of Whitman's "Letters from a Travelling Bachelor," which appeared in the New York Sunday Dispatch in 1849-1850 before disappearing from memory, until Joseph J. Rubin rediscovered and published them in $1973 .{ }^{6}$ The list goes on and on. ${ }^{7}$ All told, scholars have easily rediscovered more than one hundred thousand words of Whitmanian journalism, to which vague figure I am happy to add a further forty-seven thousand in the form of "Manly Health and Training" (1858), Whitman's forgotten, book-length guide to living healthily in America.

During his lifetime, the poet seems to have wasted no time reminding anyone of this series, nor any of the others listed above - and, given Whitman's horror of disappearance, we might ask why. It is possible that Whitman simply forgot about his articles, though I doubt it. Perhaps it is because these recovered works tend toward the editorial, interesting as often as not for how un-Whitmanian, even unpoetic, they can be. ${ }^{8}$ Or perhaps they did not, in Whitman's estimate, dovetail properly with the political scope or poetic philosophy of Leaves of Grass. Both "New York Dissected" and "Letters from a Travelling Bachelor," for instance, are geographically narrower, addressed to one specific region rather than a "teeming nation of nations." And tonally, the "Paumanok" letters are too overtly aggressive and political, favoring, as the "Dissected" series does, the topical over the eternal. "Manly Health and Training" is a similarly square peg. Though every bit as concrete and optimistic as Leaves, the "Manly Health" series' function is fundamentally utilitarian, a physiological and political document rooted in the (pseudo)sciences of the era. These fields, phrenology and eugenics especially, inspired a surprising amount of Whitman's poetic and political thought, as scholars such as Harold Aspiz and M. Jimmie Killingsworth have convincingly demonstrated. Even so, Whitman was quite careful to obscure such origins in his lifelong effort to portray Leaves of Grass as a purely ex nihilo creation. It is not one, of course. Ralph Waldo Emerson, awed as he was by 
it, knew enough to conclude that Leaves of Grass "must have had a long foreground somewhere." ${ }^{" 10}$ Whitman, diligent engineer of his own reputation, seems not to have wanted that foreground to distract from a life's work that he saw beginning with the 1855 Leaves. Thus, the long submergence of "Manly Health and Training" may constitute yet another instance of Whitman's careerist revisionism.

Readers with the self-control not to have skipped ahead to it, may be wondering: what is "Manly Health and Training," anyway? It is a good question, for which there is more than one proper answer. It is part guest editorial, part self-help column, published in the New York Atlas. At first, it reads as a fairly straightforward diet-and-exercise guide for men, yet, over its course, the series accretes additional genres. In the end, one might call it lots of things: an essay on male beauty, a chauvinistic screed, a sports memoir, a eugenics manifesto, a description of New York daily life, an anecdotal history of longevity, or a pseudoscientific tract. The series is a genre-bender; apparently, few topics were out of bounds for Whitman. ${ }^{11}$ In this special double issue of the Walt Whitman Quarterly Review, the Walt Whitman Studies Association is proud to reprint "Manly Health and Training" in its entirety for the first time ever. ${ }^{12}$

The full series covers a huge range of topics: not only diet and exercise, but also physical beauty, manly comradeship, sex and reproduction, socialization, race, eugenics, war, climate, longevity, bathing, prizefighting, gymnastics, baseball, footwear, facial hair, depression, alcohol, and prostitution. It is an eyebrow-raising document at times. Readers should prepare to encounter a more-than-typically self-contradictory Whitman; his primary claims tilt from visionary to reactionary, commonsensical to nonsensical, egalitarian to racist, pacific to bloodthirsty - and back again. In my opinion, these contradictions display little of the poetic dialecticism of Leaves of Grass. Occasionally, they seem like genuine errors. Nevertheless, the series as a whole casts fascinating light onto Whitman's poetry, particularly the dozens of new verses written for his third edition of Leaves of Grass (1860-61). "Manly Health and Training" also helps further define Whitman's transition of persona, from journalist to bard. ${ }^{13}$ And, of course, the existence of the series provides a bit of much-needed biographical 
information about Whitman in 1858: his business occupations, opinions in early middle age, and daily habits of life.

In the chronology of Whitman's life, 1858 is something of an absent year, though from the little scholars have found, it probably was not a good one. ${ }^{14}$ The year before, Whitman had suddenly found steady work hard to come by, thanks to the disastrous financial Panic of 1857. Having just proffered himself in his first and second editions of Leaves of Grass as an inspired "loafer," an Emersonian bard of the futurewith Emerson's own ostensible seal of approval - the Whitman of 1858 nevertheless had to make do, again, with newspaper work, this time for the Brooklyn Daily Times. ${ }^{15} 1858$ is also the year in which Whitman first felt a failing of his self-celebrated "perfect health." In the summer, he suffered some sort of event, a "sunstroke," that David S. Reynolds attributes to high blood pressure (and presumably, overwork) ${ }^{16}$ One of the few things we know for sure of Whitman in 1858 is that he fell into a major depression, the roots of which can only be guessed at. Some of it may have been lovesickness, or perhaps a gay man's claustrophobia in the closet. Of the few poems whose composition scholars have dated tentatively to this year, his most celebrated piece- "Live Oak with Moss"-expresses the joys and sorrows of a brief, incandescent relationship with another man, or men. Whoever was the object of this love affair, Whitman clearly felt he had no one to talk to about it: "I dare not tell it in words," he writes, "not even in these songs." ${ }^{\prime 17}$

Family relationships seem to have worsened this depression. The poet's beloved brother Jeff was then growing closer with his sweetheart, and soon-to-be wife, Martha Mitchell — whom Walt loved very much, but who doubtless left Jeff less time to spend with his brother. Those fraternal bonds that had drawn so snug in New Orleans ten years before were probably beginning to loosen.${ }^{18}$ Likewise, the death three years earlier of Whitman's unpleasant father, while a liberation for the young poet, may nevertheless have left him with a nagging, complex ache inside. Walter, Sr. had softened toward the end, though he had remained a stubborn, longtime alcoholic - hence, in many of Whitman's early writings we see his commitment, however superficial, to a total abstinence from alcohol. By 1858 , though, Whitman made 
few pretenses to teetotalling, in print or practice. In fact, he spent many nights drinking at Pfaff's Beer Hall in Manhattan, a popular spot for New York's young bohemians, freethinkers, and sarcastic literati. Some of this was calculated. Of his uncharacteristic night-owling, Ed Folsom and Kenneth Price note that Whitman "was clearly remaking his image, going to bars more often than he had since he left New Orleans a decade earlier." ${ }^{\prime 19}$ That is, his time at Pfaff's seems to have been the poet's effort at rebranding, not recovering. There, Whitman quietly greeted friends and enemies alike, and occasionally heard his Leaves of Grass made the butt of less-than-subtle jokes. Public reviews of the poem from this period are disheartening; a particularly vicious December review in the Long-Islander, a paper Whitman himself had founded, disposes of Leaves of Grass as "a repulsive and nasty book." ${ }^{20}$

It is easy to see why Whitman might have begun to question his identity as a poet. In a poem written around this period, eventually titled "As I Ebb'd with the Ocean of Life," he expresses anxiety about his calling:

I have not once had the least idea who or what I am,

But that before all my insolent poems the real ME still stands untouched, untold, altogether unreached,

Withdrawn far, mocking me with mock-congratulatory signs and bows, With peals of distant ironical laughter at every word I have written or shall write, Striking me with insults till I fall helpless upon the sand. ${ }^{21}$

More than a few commentators point to this period (1858-60) as Whitman's mid-life crisis - and, for the literal-minded, it does indeed fall near the center of his seventy-two years. Clearly, the poet suffered some crisis of identity beginning in 1858, such that he felt the need to test other outlets, social or sexual. Whitman probably began "Live Oak," his most homoerotic poetic sequence, late in 1858, and Christine Stansell notes that it is during this same period that Whitman "regularly socialized with a group of young male friends-'the beautiful young men?'- dubbed the 'Fred Gray Association' after one of their principals." ${ }^{2}$ However, excepting his participation in what may have been an underground society for gay men, Whitman would recall this time as a brief period of social conformity, in which he drank as 
other writers drank, talked as they talked, and even dressed as they dressed. In a photograph from this brief period, taken by Boston photographer J. W. Black, ${ }^{23}$ we see Whitman wearing the dark, baggy suit, with pinstriped vest and pants that characterized those writers who identified themselves as "Bohemians." It is little wonder that, thirty years after the fact, Whitman said of the portrait that "it is me, me, unformed, undeveloped," that it "hits off phases not common in my photos." ${ }^{24}$ In a life increasingly defined by self-assurance, 1858 was indeed an uncommon phase. It was a year of self-questioning.

Whitman's uncertainty is perhaps most evident in his correspondence and notebooks from the period, in which he toys with the idea of boldly changing his profession altogether. In a letter draft dated July 28, 1857, he writes that "I have thought, for some time past, of beginning the use of myself as a public Speaker, teacher, or lecturer."25 The next spring, on his thirty-ninth birthday, Whitman expands on this thought in a notebook, framing his choice of profession as nothing short of a national imperative:

\section{May 31. '58.}

It seems to me called for to inaugurate a revolution in American oratory, to change it from the excessively diffuse and impromptu character it has, (an ephemeral readiness, surface animation, the stamp of the daily newspaper, to be dismissed as soon as the next day's paper appears.) — and to make it the means of the grand modernized delivery of live modern orations, appropriate to America, appropriate to the world.- (May 31-2) This change is a serious one, and, if to be done at all cannot be done easily.- A great leading representative man, with perfect power, perfect confidence in his power, persevering, with repeated specimens, ranging up and down 'The States-such a man, above all things, would give it a fair start. - What are your theories? - Let us have the practical sample of a thing, and look upon it, and listen to it, and turn it about for to examine it.-

Washington made free the body of America, for that was first in order-Now comes one who will make free the American soul. ${ }^{26}$

Similar passages pepper Whitman's notebooks of the period. There are many echoes here of Emerson-even a reference, perhaps, to his Representative Men (1855)—but it should probably go without saying that Whitman's "great leading representative man" is himself. It is not all that surprising that the Whitman of 1858 briefly imagined himself 
as the next Emerson or Webster, the great national orator of his age. As F. O. Matthiessen well demonstrates, Whitman's poetry was deeply rooted in - and, in some manuscripts, indistinguishable from-oratory. ${ }^{27}$ Whitman's attachment to oratory began early, when as a boy he heard the great Quaker speaker Elias Hicks deliver a commanding oration in Brooklyn. This love of vocal performance became a passion in the 1850s, when he began attending Italian operas; in the decade following there appear in his notebooks dozens of specific reminders to himself about how to enrich the timbre of one's voice, and expand the chest, and "restrain gesture," so that an audience might in the end find one's voice, speech, and presence irresistible. ${ }^{28}$ By 1858, his commitment to transforming himself into a national orator was such that Whitman ventured that "Lecturing, (my own way,) [is] henceforth my employment, my means of earning my living" (NUPM 4:1437). He even drafted programs for a projected lecture series (see image on the Back Cover), the subject being nothing less than the nation itself:

America

A Programme, \&c.

Some plan I seek, to have the vocal delivery of my lectures free; but at present a low price of admission, One Dime - Or my fee for reciting, here, $\$ 10$, (when any distance expenses in addition.)

Each Lecture will be printed, with its recitation; needing to be carefully perused afterward, to be understood. I personally sell the printed copies.-

\section{Brooklyn, New York}

1858.

(NUPM 4:1437)

Whitman is not known to have delivered any such lectures. Besides some early political orations, and his annual reminiscences of Abraham Lincoln delivered later in maturity, Whitman's employment as a lecturer was infrequent. A skepticism of his own oratorical abilities may have had something to do with this. For all Whitman's excitement at the prospect of lecturing on America, he seems to have doubted that he would get his ideas across, given his insistence that his words will have to be "carefully perused afterward, to be understood" (NUPM 4:1437). (Of course, it is equally possible that Whitman was simply 
fishing for extra cash.) Yet, the realization of these lectures matters less than Whitman's impulse to lecture, born of a poet who was tiring of the next-to-meaningless "stamp of the daily newspaper, to be dismissed as soon as the next day's paper appears" (NUPM 6:2233). Indeed, Whitman's Daily Times editorials from the period are often unrewarding reading. Short, ephemeral things, many of them sound as if they were dashed off in under an hour. From what little we know of him in 1858, Whitman must have longed to escape this "surface animation" of editorial journalism, in order to "make free the American soul"and his own soul in the process (NUPM 6:2233-4). But, as his poetry and notebooks both insist, to free the soul one must begin by freeing the body, "for that [is] first in order" (NUPM 6:2234).

This priority may explain why, in 1858, Whitman dreamed up a pair of draft advertisements for a proposed series of articles on "Manly Health and Training" (NUPM 6:2257). They promise a series "not only original and of a high degree of literary merit, but go[ing] into full practical details, giving that specific advice in all departments of general training for health, whose result, if faithfully followed, would be, for every man who reads it, A NOBLE AND ROBUST PHYSIQUE." Scholars have long been aware of these handwritten drafts, as well as an evidently related stack of notes on the subjects of physique, exercise, temperance, and longevity (NUPM 6:2248-59). Thomas B. Harned, Whitman's friend and literary co-executor, presented them before the Walt Whitman Fellowship as early as $1898 .{ }^{29}$ The ultimate application of these manuscript drafts, if any, has always been uncertain. Had Whitman begun a series, only to have it fall through? Or, in preparing an abortive lecture on physique, perhaps, had he merely fiddled with the idea of making it into articles instead? (After all, he went so far as to draft a program for non-existent lectures.) Scholars Edward F. Grier and Brett Barney have raised similar questions, but, in absence of further evidence, there has been nothing on which to even hazard a guess. ${ }^{30}$

Now, there is further evidence. It lay shut away for over 150 years in the New York Atlas, a Manhattan weekly that today is quite difficult to get one's hands on. (Like many newspapers associated with Whitman, it has not been digitized. Few copies exist today, even on 
microfilm.) In the September 12 issue of the Atlas for 1858, on page 4, appears the following notice:

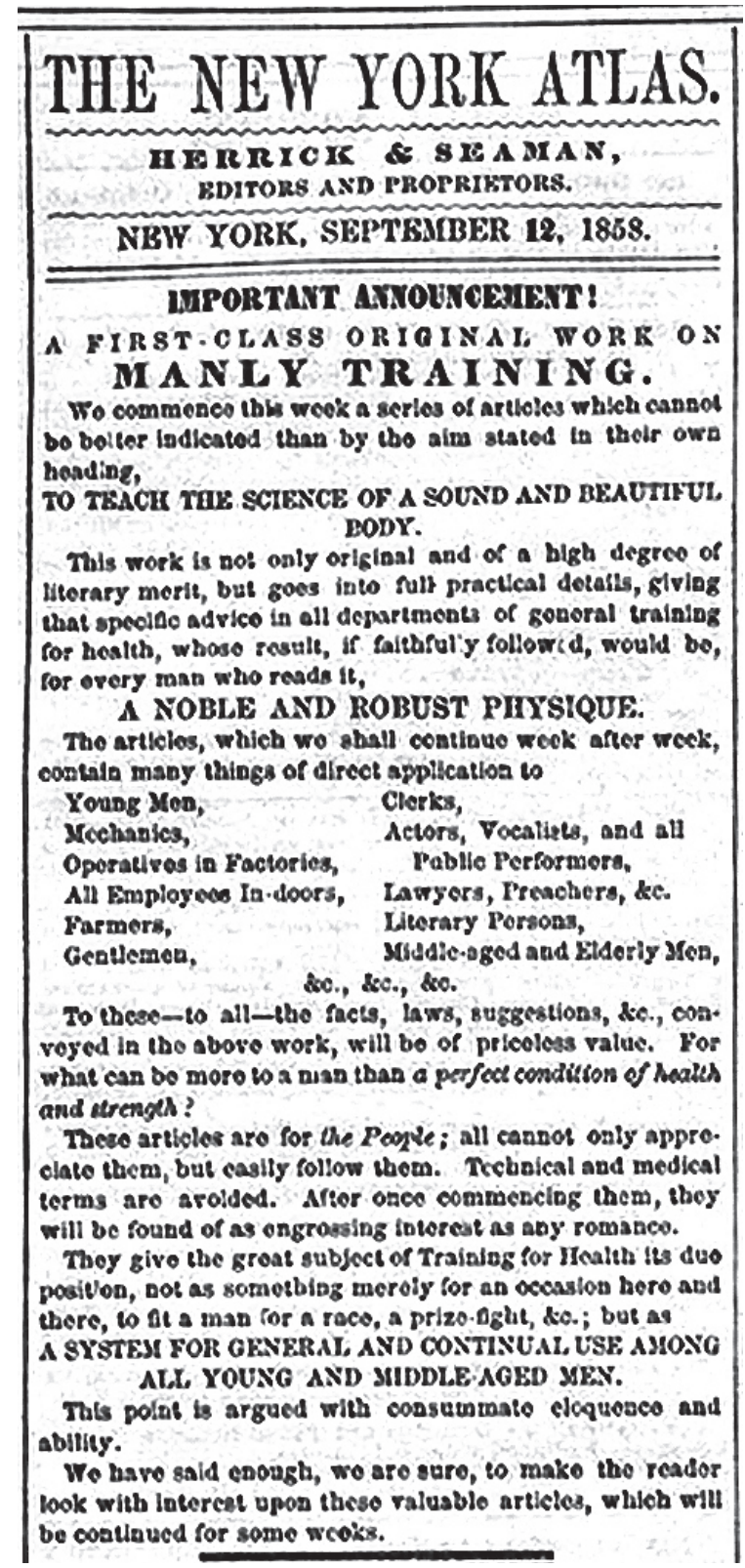

Figure 1. Advertisement for "Manly Health," as found in the New York Atlas, for September 12, 1858:4. Courtesy of the American Antiquarian Society. 
This ad matches almost exactly one of Whitman's "Manly Training" manuscript notices (NUPM 6:2255-6). Whitman drafted it with just a few rewordings, and it seems to have been accepted as-is; his capitalizations, italics, columns, and indents are largely maintained. There is no doubt that it is his. The series itself, commencing that week in the Atlas, is also his; it appears under the full title "Manly Health and Training, with Off-Hand Hints Toward Their Conditions." Published in thirteen total installments under the byline "Mose Velsor, of Brooklyn," the series begins September 12 (the same issue as the advertisement) and ends December 26, with a few gap weeks (see Figures 2 and 3 for images of the opening installment). ${ }^{31}$

Beyond the symmetry between Whitman's draft ad and the finalized advertisement, additional bibliographic evidence establishes the poet's authorship of the series. First, of Whitman's many pen names "Mose Velsor, of Brooklyn" was one of his favorites. ${ }^{32}$ By 1858, he had already used it a number of times-as when, three years earlier, he signed it to both a Life Illustrated article on "The Opera" and an unpublished manuscript about "A Visit to the Opera" (NUPM 1:391). The pseudonym appears as early as 1848 , in an article Whitman wrote for the New Orleans Daily Crescent on the "b'hoys of the Bowery." 33 Second, in the same batch of health-related manuscripts, one may find draft versions of language that appears in "Manly Health and Training," including both Whitman's own words and quotations cribbed from a source familiar to Whitman - Fowler and Wells' WaterCure fournal-for use in the series (see NUPM 6:2248-54).

The Whitman of "Manly Health and Training" is not so much the correspondent on the street - an observer of faces and bodies on Broadway, à la "New York Dissected"- as he is a shameless plunderer of books and magazines. Perhaps more than any other piece of sustained journalism Whitman wrote, "Manly Health and Training" is chock-a-block with quotations from, and outright theft of, other periodical writings. It is quite likely his most plagiarized work. Curiously, many of its sources have already been established, thanks to the work of scholar William L. Finkel. In 1950, Finkel determined that Whitman's handwritten notes on physique and health - notes, it is now clear, for "Manly Health and Training" — had been copied, often verbatim, from 


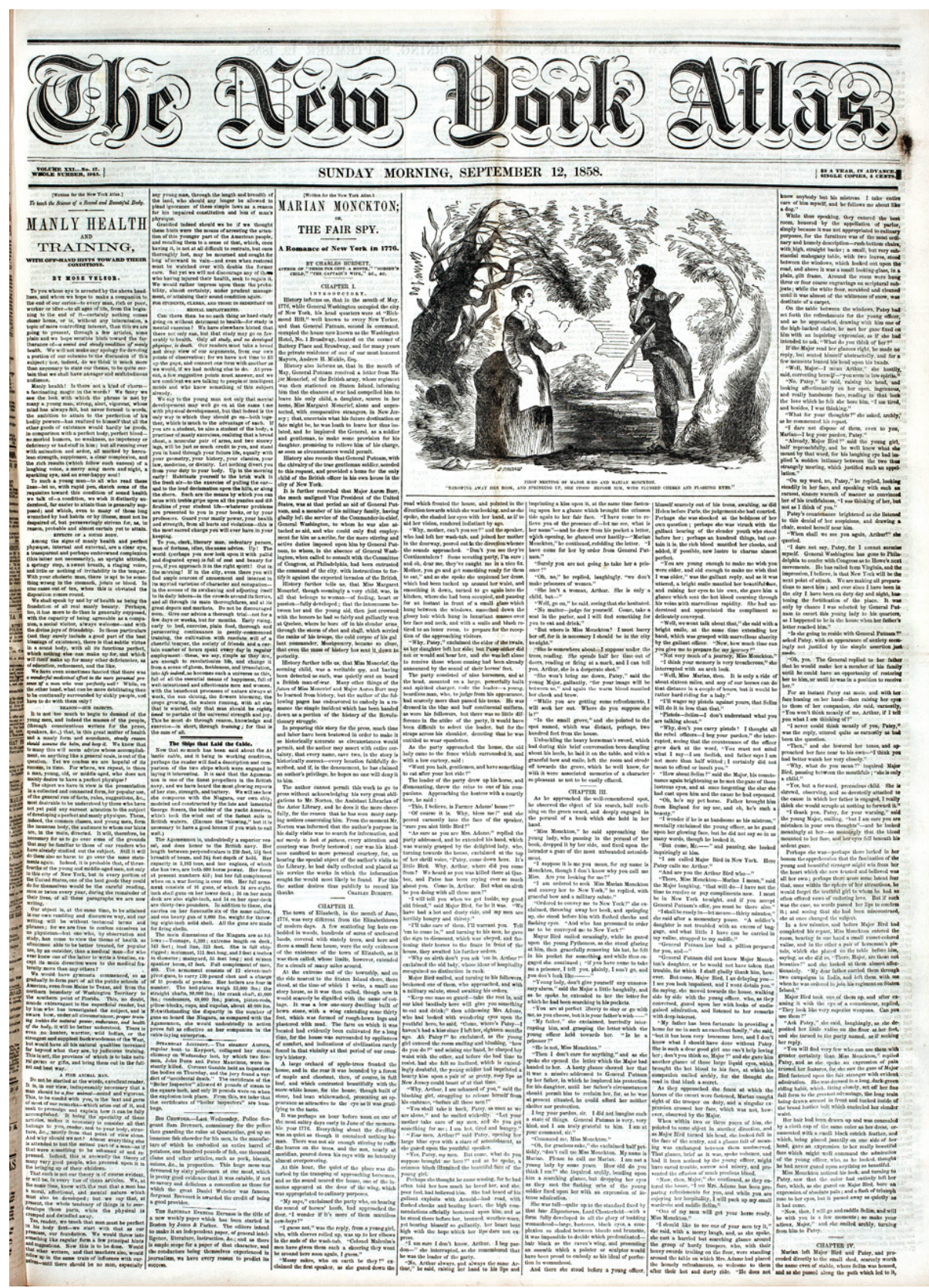

Figure 2. First page of the New York Atlas of September 12, 1858, featuring the first installment of "Manly Health" (left side). Courtesy of the American Antiquarian Society. 
[Written for the New York Atlas.]

To wach the Science of a Sound and Beautiful Body.

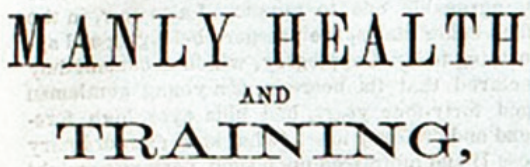
WTTH OFF-HAND HIST TOWARD THEIR
CONDITONS.

\section{B Y MOSE VELSOB.}

To you whose oyo is arrested by the above hesd. lines, and whom wo hope to make a companion to the end of our series - to every man, rlch or poor, worker or idler-to all ages of life, from the beginning to the end of it-certainly nothing comes closer home, or is, without any intermission, a topic of more controlling interest, than this we aro going to present, through a fow articles, some plain and we hope sensible bints toward the furtherance of $-a$ soumd and steady condition of manly health. Wo will not make any appology for devoting a portion of our columns to the discussion of th/s subject; nor, fndeed, do we think it much more than necessary to state our theme, to be quite certhin that we shall have aneager and multitudinous audience.

Manly health! Is there not a kind of charma fascinatiog magio in the words? Wo fancy wo seo the look with which the phrase is mot by many a young man, strong, alert, vigorous, whoso mind has always felt, but nevor formed fn words, the ambition to attain to the perfection of his bodily powers-has realized to himself that all the other goods of existence would hardly be goods, in comparison with a perfect body, perfect bloodno morbid humors, no weakness, no impotency or deficiency or bad stuff in him; but all running over with animation and ardor, all marked by herculean strength, suppleness, a clear complexion, and the rich results (which follow such causes) of a laughing voice, a merry song morn and night, a spariking eye, and an over-bappy soul!

To such a young man-to all who read these unes-let us, with rapid pen, sketch some of the requisites toward this condition of sound health we talk of - a condition, we wish it distinctly un. derstood, far easler to attain than is generally supposed; and which, even to many of those long wrenched by bad habits or by lllness, must not be decpaired of, but persoveringly striven for, as, in reason, probable and almost certain yet to attain. EPTECTS OP A SOEND BODY.

Among the signs of manly bealth and perfect physique, internal and external, are a clear eye, a transparent and perhaps embrowned complexion (this latter not necessarily), an upright attitude, a springy step, a sweet breath, a ringing voice, and little or nothing of irritability in the temner. any young mas, through the length and breadth of the land, who should any longer be allowed to plead ignorance of these simple laws as a reason for his impaired constitution and loss of man's physique.

Gratified indeed should we be if wo thought these hints were the means of arresting the atten. tion of this younger part of the $A$ merican people, and recalling them to a sense of that, which, once having it, is not at all dimicult to restrain, but once thorougbly lost, may be mourned and sougbt for long afterward in vain-and oven when restored must be watched over with double the former eare. But yet wo will not discourage any of thes who having injured their bealth, seek to regain it. We would rather impress upon them the proba. bility, almost certainty, under prudent management, of attaining their sound condition again. POR STUDEXTY, CLERKS, AND THOSE IN SEDENTARY OR XENTAL EMPLOYXESTS.

Can there then be no such thing as hard study going en without detriment to health-for study is mental exercise? Wo havo elsowhere binted that there not only can, but that study may go on fav. orably to health. Only all study, and no developed physique, is death. Our readers must take a broad and deep view of our arguments, from our own polnts of observation; for we have not time to fill up the gaps, and connect one item with another as wo would, if wo had nothing else to do. At pres. ent, a few suggestivo points must answer, and we are contedent we are talking to people of intelligent minds and who know somothing of this subject already.

We say to the young man not onls that mental developement may well go on at the same t me with physical developement, but thst Indeed is the only way in which they should go on-both together, which is much to the advantage of each. If you are a student, be also a student of the body, a practiser of manly exercises, realizing that a broad chest, a muscular pair of arms, and two sinewy legs, will bo just as much credit to you, and stand you in hand through your future life, equally with your geometry, your history, your classice, your law, medicine, or divinity. Let nothing divert you from your duty to your body. Up in the morning early! Habituate yourself to the brisk walk in the fresh air-to the exercise of pulling the oarand to the loud declamation upon the hills, or along the shore. Such are the moans by which you cad seize with treble gripe upon all the puzzles and dif. nculties of your student life-whatever problems are presented to you in your books, or by your professor s. Guard your manly power, your health and strength, from all hurts and violations - this is the roost sacred charge you will ever have in your keeping.

To you, clerk, literary man, sedentary person, man of fortune, idler, the same advice. Up! The world (perbaps you now look upon it with pallid and disgusted eyes) is full of zest and beauty for you, if you approach it in the right spirit! Out in

Figure 3. Detail of the first installment of "Manly Health" from the New York Atlas of September 12, 1858:1. Courtesy of the American

Antiquarian Society. 
several New York periodicals, including the Water-Cure fournal, Hall's Fournal of Health, the Harbinger, and the World. ${ }^{34}$ As Finkel's research makes clear, Whitman carefully copied out long passages from these magazines - or, just as often, passages from books excerpted in these magazines - with some idea of making use of them, though Finkel did not have the luxury of knowing that use. Now, with "Manly Health and Training" in hand, I can confirm that Finkel was correct in his assumption that, using these passages, "Whitman intended 'To present a Case of the Condition of Perfect Health' in prose." ${ }^{.35}$ Furthermore, the list of periodical sources to which Whitman turned can now be expanded to include magazines like the American Phrenological fournal and Miscellany, Life Illustrated, and Harper's Weekly. It is also clear that the poet borrowed covertly from books on health, longevity, and exercise, including John William Orr's Book of Swimming (New York: J. W. and N. Orr, 1846); the Census of the State of New York, for 1855 (Albany: Charles Van Benthuysen, 1857); and John Eisenberg's Surgical and Practical Observations on the Diseases of the Human Foot (London: Henry Renshaw, 1845). Whitman also openly quotes from a number of additional books, at least a dozen more, but these mostly appear to have come to his attention as excerpts in the Water-Cure fournal - which, alongside the American Phrenological fournal, seems to have been Whitman's primary source for health information while writing the series. It should be noted that, regardless of source, most installments of "Manly Health and Training" are almost entirely in Whitman's own words. Only in a few of them does Whitman brazenly plagiarize, a practice that strongly differentiates his journalism from his poetry.

In verse, Whitman was quite careful to eliminate the traces of his poetic influences, borrowings, and appropriations. In early notebooks, he reminds himself to write verses as if they came to be ex nihilo, and so, in the early editions of Leaves of Grass especially, his poetics often give the reader a sense of being unprecedented. Not that they are; Whitman felt the influence of many poets, including Homer, Aeschylus, Sophocles, Christ, Ossian, Dante, Spenser, Shakespeare, Milton, Goethe, Walter Scott, and even Poe, in a negative sort of way. ${ }^{36}$ "Every great artist, poet, etc., will be found to have some precursors 
or first beginners of his greatness," Whitman wrote in his notebooks, adding that "doubtless Homer had though we know them not" (NUPM 1:372). But he privately expressed a desire to transcend his influences, noting to himself in or around 1857 that "I will be also a master after my own kind" (NUPM 4:1434, emphasis mine). Thus, he took great care early on to obscure his place within poetic tradition, though, as Kenneth Price has documented, later in his career Whitman returned somewhat to conventionality. ${ }^{37}$ It has taken scholars more than a century to tease back out Whitman's many borrowings. ${ }^{38}$

In "Manly Health and Training," Whitman is far less conscientious about hiding his appropriations; his historical installments in particular, on ancient Greek athleticism and American longevity, lift liberally from other sources. Those installments that do not are still prone to repetition, discrepancy, even back-peddling. If nothing else, we may deduce from this haphazardness a few of the circumstances behind the writing of the series. First, it is clear that Whitman wrote in haste. His literary output in this period, between the second and third editions of Leaves of Grass (1857-1860), was prolific, even for him. In 1857 alone, Whitman wrote close to seventy new poems, in what Gregory Eiselein calls "an explosion of poetic production.." ${ }^{39} \mathrm{He}$ spent a great deal of energy trying to get these verses into a new edition of Leaves, though it would not be until three years later that any publishing house would offer to prepare an updated edition. Additionally, beginning in the spring of 1857 , Whitman edited and wrote for the Brooklyn Daily Times, requiring of him several hundred (or even thousand) words per day, six days a week, for two straight years. Given that there is no obvious break in Whitman's editorials in the Daily Times during the period of publication of "Manly Health and Training," it is clear that he created the series in addition to his editorial dutiesno mean feat, considering that the series added roughly 3,000 words to Whitman's weekly workload. It is little wonder that virtually no correspondence to or from Whitman exists for this period-he can hardly have had left any time, energy, or ink.

Besides the haste in which it must have been written, we can assume that Whitman's motives for writing "Manly Health and Training" were at least partially financial. His first edition of Leaves of Grass (1855) 
had sold poorly; many of the copies still extant were likely given away to friends or reviewers, rather than purchased. The second edition (1856) fared even worse; Harold Aspiz calls it "Whitman's greatest publishing failure." ${ }^{.40}$ It cannot have helped that its publishers and retailers, Fowler and Wells, were not poets by any measure. They specialized primarily in books on phrenology, physiology, and self-culture for young people. Add to this the Panic of 1857, a year in which Whitman found himself slapped with a lawsuit for loan default, and it becomes likely that the poet's finances expanded the breadth and pace of his journalistic efforts. "Manly Health and Training" is thus probably best categorized as a side project, one of several freelance jobs Whitman took on during this period, anonymously or pseudonymously, for extra cash. Other notable examples are the "New York Dissected" series (1856), published in Fowler and Wells' Life Illustrated magazine, and Swinton's Rambles Among Words (1859). It is entirely possible that there are more instances, as yet unknown.

Currently, I have located no correspondence or business documents related to the publication of "Manly Health and Training" in the Atlas. However, simply knowing in which paper the series appeared offers a bit of insight into Whitman's editorial and journalistic connections at the time. The Atlas was founded in 1838 as the Sunday Morning Atlas, by the editorial duo of Anson Herrick and Jesse Fell. After Fell's departure, Herrick was joined by long-time editor John F. Ropes. ${ }^{42}$ By the time "Manly Health and Training" made its appearance, the paper had become the New York Atlas, a well-circulated weekly known for its literature and for advocating in favor of workers' rights..$^{43}$ The poet had long been familiar with it; he and his brother, Jeff, read the Atlas together as early as 1848, during their year in New Orleans. ${ }^{44}$ Even before then, Whitman was well aware of the paper. Its proprietors, Herrick and Ropes, also co-owned the Aurora, a New York daily for which Whitman had served as editor for a mere two months in 1842 . The two papers even shared the same headquarters. ${ }^{45}$ Here is how the Atlas is described in the Aurora:

This large and beautifully printed paper, published every Sunday morning, is devoted to literature, the fine arts, the drama, and the news of the day. Its 
standing as one of the most popular weekly papers in the country, is universally acknowledged. Its prominent features are, its original Portraits and Sketches of American character ... - original tales and sketches - theatrical reports- "odds and ends," comprising all the intelligence, wit, humor, and sentiment, from the English and American newspapers. ${ }^{46}$

This advertisement appeared on the front page of nearly every issue of the Aurora Whitman edited (February-April 1842). Though he was responsible for the majority of the Aurora's daily copy during his brief tenure as editor-contributing items on politics, public education, immigration, and street life-Herrick and Ropes nevertheless found Whitman to be "the laziest fellow who ever undertook to edit a city paper." ${ }^{\prime 47}$ Herrick in particular seems to have been at loggerheads with him - at least, that is how others remembered their relationship. Recalling their fights some sixty years later, William Cauldwell, a printer on the Aurora, noted that Whitman and Herrick clashed most often over the paper's political tone:

According to agreement, as I could understand, Whitman was to have full swing to write just what he chose in any other part of the paper (of course not antagonistic to its politics), but the senior proprietor, Herrick, who ran the political crank, was to have the toning of its leaders. "If you want such stuff in The Aurora, write it yourself," Whitman more than once said to Herrick. . . . After the expiration of the term for which Whitman had engaged he had had, as he said, enough of editing a party "organ," and he sundered his relations with The Aurora. ${ }^{48}$

The budding poet, then twenty-two, quickly landed a position at another daily paper, the Evening Tattler, wherein he vented his feelings about Herrick and Ropes: "There is in this city a trashy, scurrilous, and obscene daily paper, under charge of two as dirty fellows, as ever were able by the force of brass, ignorance of their own ignorance, and a coarse manner of familiarity, to push themselves among gentlemen" (Reynolds 102). The "dirty fellows" shot back that they were fully aware of "a small, 'obscure daily' now under the control of a 'pretty pup' once in our employment; but whose indolence, incompetence, loaferism and blackguard habits forced [us] to kick him out of office" (Reynolds 102). The "pup" was not long for the Tattler, anyway; he would leave after two or three months. 
Sixteen years later, Whitman's entrée into the pages of the Atlas was probably none other than that "dirty fellow" Anson Herrick, who still owned the Sunday-only paper, now with partner A.G. Seaman. By this time, Whitman's relationship with Herrick is unclear, though probably it was still a little prickly. Two years later, in 1860, Herrick would dispose of Whitman's "Broadway Pageant" (published in the New York Times) as "incomprehensible, egotistic twaddle" written by a "rough, shaggy, pea-jacketed individual." 49 Yet the editor would concede Whitman's personal kindness, based on a news item that the poet had driven a Broadway stage for a driver who had fallen ill: "Whitman's poetry is very bad, and so are his garments-but his heart is sound enough. ${ }^{{ }^{50}}$ For his part, scholar Joseph Jay Rubin emphasizes that this compliment primarily indicates Herrick's awareness of "the growing reputation of his former editor." ${ }^{51}$ But that was in 1860; in 1858, Whitman's reputation still had a ways to go, hence his recourse to the Atlas may indicate his financial need. After all, he was editor and writer for the Brooklyn Daily Times, a Republican paper politically the opposite of the Atlas. To publish openly in a rival paper might have endangered his job, which almost certainly explains Whitman's use of a pseudonym-“Mose Velsor, of Brooklyn."

However, it does not quite explain why Herrick would agree to publish Whitman in the first place. After all, the Daily Times regularly belittled Herrick's character, before and even during the publication of "Manly Health and Training." On October 20, for example, it is said of Herrick's chances in a district election that

Anson Herrick, of the Sunday Atlas, has been selected by the Custom House clique, in the 8th Congressional District, for the honor of being beaten by $\mathrm{Mr}$. Horace F. Clarke. Herrick is as apt a representative of the slavishly obedient partizan as could be found, and therefore a fit man to contest the district against Mr. Clarke, on the issue that "the President can do no wrong." 52

The Daily Times also reprints an unflattering item from the Evening Post three days later: "The last time [Herrick] was before the people he was a candidate for State's Prison, and polled a two-third vote from a Sessions jury. ${ }^{33}$ It is tempting to think that the two men still held some venom in reserve for one another, but it is more likely that 
by this time, their hot remarks were primarily public theater. Vituperative as he could be, Herrick had once been willing to call Whitman "a bold, energetic and original writer." ${ }^{54}$ And Whitman did not necessarily write those editorials blasting Herrick's political chances; Karen Karbiener suggests that some of the Daily Times editorials were written by proprietor and sometime editor George C. Bennett, giving Whitman some leeway (if not outright permission) to write poetry and freelance journalism at his own editorial desk. ${ }^{55}$ Furthermore, while it is odd to think that Herrick might have allowed the creator of what he called "dirty 'Leaves of Grass" to discuss men's bodies in the pages of the Atlas, that does not make it impossible. ${ }^{56}$ Herrick was not an idiot, after all. It is difficult to imagine that he had no idea who "Mose Velsor" was-nor does there seem to have been much need for Whitman to hide his identity from Herrick. Less than a month after Whitman had quit the Aurora and publicly called Herrick "a dirty fellow . . . ignoran[t] of [his] own ignorance," his short story "Reuben's Last Wish" appeared in yet another Herrick and Ropes newspaper, the New York Washingtonian. The byline, "by Walter Whitman," hides nothing. A second story by Whitman, "The Madman," would appear in the same paper, now called the Washingtonian and Organ, the following year (January 1843). Herrick knew full well who he was publishing, suggesting that their journalistic back-and-forth may have been more exaggerated than either man let on. ${ }^{57}$ And if, as Jerome Loving insists, Whitman and Herrick's parting was not nearly as vitriolic as their printed accounts make it seem, then it is entirely possible that "Manly Health and Training" appeared with Herrick's assent, or even approval. ${ }^{58}$ Regardless of what Whitman had said about him, Herrick still needed his columns filled —in 1842-1843, and again in 1858-by whomever he could scrape up, Whitman included.

Assuming Herrick's knowledge, the details of how Whitman saw "Manly Health and Training" through the editorial process are still, for now, unclear. Why the Atlas, rather than some other paper-did it pay the most? Was it the only paper willing to buy Whitman's columns? How much did he earn for the series? Did Whitman suggest a series on "manly training" to the Atlas's proprietors, or did they solicit it from him? How did he conduct his business with the Atlas? For how long 
was he initially contracted with the Atlas? Besides the last of these, all such questions must remain unanswered until further evidence turns up.

Regarding Whitman's contract, there is a paratextual hint that "Manly Health and Training" was originally set to appear in eleven installments, not thirteen. At the end of the tenth installment (November 28) - after discussions of "VIRILITY," "PROSTITUTION," "MUSCULAR POWER AND ENDURANCE," "LOCOMOTION," "THE CARE OF THE FEET," and "DANCING" - the author indicates that the series will be "CONCLUDED NEXT WEEK." 59 Yet, the following week, no installment appears at all. Instead, on December 12, the series reappears, marked "Continued" as usual, after which two further installments are published, on December 19 and 26. In the penultimate, the author notes that "for these two concluding numbers of our series, we find we have a few more items to give." ${ }^{90}$ Whitman maintains the first-person plural throughout the series, so its presence here does not help clarify who made this decision. But, regardless of how he did it, it looks as if Whitman may have wangled an extra two installments out of Herrick and Seaman. One might argue that it was the other way around, that the editors asked an extra two of him, but the series' gradual migration from the front page to further back in the paper suggests that its readers (or editors) were losing interest.

Of what interest is "Manly Health and Training" today? Certainly it contributes substantially to our understanding of a dimly recorded period in Whitman's life. But what makes this series especially important are the added dimensions it lends to Whitman's poetry of the period, and, better still, the ways in which it complicates the democratic and egalitarian ethics of Leaves of Grass. There is a great deal to say on these subjects, on which I will offer just a few preliminary observations.

"Manly health" - that is, idealized masculinity—is a major motif in Leaves of Grass, particularly in those poems written expressly for the third edition, celebrating the vigor and fertility of a new "American race." Whitman conceived of his poetry itself as masculine work, something "American, [of] the robust, large, manly character," steeped in his 
ideals of health. ${ }^{61}$ (Health, as Whitman tends to formulate it, is premised upon manliness, making the phrase "manly health" more than a little tautological.) Conversely, good health and strength are, for Whitman, distinctly American attributes - they define "these American states strong and healthy." 62 Thus, in "Manly Health and Training," as in Leaves of Grass, the poet treats as inseparable the notions of masculinity, strength, individual health, and national character. The latter should not be underemphasized. Even the words themselves, "manly" and "health," Whitman habitually associates with nations, states, and systems, as in Rambles Among Words (1859): "How severe and stately is 'MANLY' . . how noble, how compensating! It strengthens our faith in human nature!" (Swinton 198). The etymology of "health" offers even grander associations:

The word 'HEALTH' wraps up within it-for, indeed, it is hardly a metaphor-a whole world of suggestion. It is that which healeth or causeth to be whole-what the Scotch call hale: that is, perfect 'health' is that state of the man when there is no discord or division in the system, but when all the functions conspire to make a perfect one or whole. (Swinton 69)

These same sentiments, much amplified, appear in "Manly Health and Training," with all connotations-masculine, systemic, holistic, harmonic, perfect-intact. Whitman savors the words to even more ecstatic effect here, as he sets forth his theme for his readers, "to be quite certain that we shall have an eager and multitudinous audience":

Manly health! Is there not a kind of charm - a fascinating magic in the words? We fancy we see the look with which the phrase is met by many a young man, strong, alert, vigorous, whose mind has always felt, but never formed in words, the ambition to attain to the perfection of his bodily powers- has realized to himself that all other goods of existence would hardly be goods, in comparison with a perfect body, perfect blood - no morbid humors, no weakness, no impotency or deficiency or bad stuff in him; but all running over with animation and ardor, all marked by herculean strength, suppleness, a clear complexion, and the rich results (which follow such causes) of a laughing voice, a merry song morn and night, a sparkling eye, and an ever-happy soul! ${ }^{63}$

Bodily health is, by Whitman's lights, the arena in which humanity is most perfectible. To what end? Most immediately, the goal, as stat- 
ed, is the reader's daily happiness, the "laughing voice" and "sparkling eye" that betoken "an ever-happy soul." Whitman returned to the idea of happiness often in the 1850s - as when he jotted down "a Poem theme [:] Be happy/ Going forth, seeing all the beautiful, perfect things" (NUPM 4:1342). One might take this as an overarching theme of Leaves of Grass itself, since from the very beginning "happiness" is one of Whitman's watchwords. "There is that in me . . .. I do not know what it is . . . but I know it is in me," he confesses in 1855, in a poem that would come to be titled "Song of Myself." "It is not chaos or death .... it is form and union and plan .... it is eternal life . . . it is happiness." ${ }^{94}$ Happiness is a bodily sensation, Emersonian in its immediacy: "Happiness not in another place, but this place . . not for another hour, but this hour" (Leaves of Grass 64). But Whitman also looks to it as a goal, perhaps the goal, of all action and thought; in his 1855 preface, he judges that "the eternal tendencies of all toward happiness make the only point of sane philosophy. Whatever comprehends less than that ... is of no account" (Leaves of Grass viii). Happiness, then, is another subject of "Manly Health and Training," along with health, handsomeness, and long life. Yet, none of these is quite what the series is "about." Though it is ostensibly a fitness and lifestyle manual, "Manly Health and Training" responds to deep shifts that were taking place in science, society, and politics, all driven, to one degree or another, by evolving nineteenth-century notions of natural perfectibility.

The nineteenth century was an era not only of great change, but of an increasing awareness of change as foundational to existence. In centuries prior, the great discoveries and theories made by Renaissance- and Enlightenment-era thinkers had situated humanity at the center, or nearly so, of vast, mechanistic systems. The world might change, but only in a circumscribed, purposive way, as a watch "changes" with each tick-always in obedience to higher "laws" (of nature, Newton, or the New Testament). Thus, if humanity were moving toward anything, it was long assumed to be perfection. Christian teleology had something to do with this assumption, but so did the long lag between early discoveries in the physical sciences, especially astronomy and chemistry, and those made later in the natural scienc- 
es. To scientists — or more accurately, "natural philosophers"-of the seventeenth and eighteenth centuries, apparent imperfections in the cosmos merely hid a higher perfection and complexity. When Galileo determined that Jupiter has its own moons, for example, oddities in the planet's orbit lost their oddity. Likewise, the revolutions of the planets in ellipses, rather than perfect circles, seemed a flaw in the solar system - until they inspired Newton's formulation of universal gravitation. Yet, as the natural-philosopher nobleman gave way to the "scientist"- a more middle-class profession defined by specialization and specimen-gathering-discoveries in the natural sciences, particularly biology and geology, gradually began to expose imperfection and chaos as fundamental "forces" of life on Earth. ${ }^{65}$

The progression of nineteenth-century theories of evolution provides a case in point. In 1796, French naturalist Georges Cuvier had shocked the world with the unearthed skeletons of large, elephant-like creatures. The shock was a reaction to his theory that they were not elephants at all, but in fact a large ancient species, dubbed the "mammoth," that had completely died out. ${ }^{66}$ Cuvier introduced humanity to a concept almost totally foreign to biology: extinction. It was to this new notion of annihilation that Thomas Malthus, an English cleric and statistician, would soon suggest humanity itself might be susceptible. Just two years later, in the year that saw the birth of the Romantic movement in Wordsworth and Coleridge's Lyrical Ballads, Malthus published An Essay on the Principle of Population (1798), in which he calculated that modern human populations grow too quickly to be sustainable. It was a tremendously unpopular idea, almost romantic in its sublimity. ${ }^{67}$ The success of civilization, he concluded, ensures its own collapse.

Decades later, inspired by Malthus's meditations on growth and (un)successful adaptation, British naturalists Charles Darwin and Alfred Russel Wallace would draw an even more earthshaking conclusion about nature as a whole: animal speciation - that ladder of being at whose topmost rung humanity enjoyed placing itself - was no ladder at all. Extensive observation suggested that it was a random process, driven largely by mutation and circumstances. Life, it seemed, was imperfect, evolving to no discernible end. 
Coincidentally, Darwin and Wallace's findings first appeared in print in August 1858, just days before the publication of the initial installment of "Manly Health and Training." (Whitman almost certainly had no knowledge of Darwin until a year or two later.) The idea of true randomness in nature-unpredictable, fluctuating, purposeless-seemed to fly in the face of all teleological thinking, scientific or religious, and it met with resistance, to put it mildly. Some thinkers rejected Darwinism outright. Others, Whitman among them, adapted it (or misunderstood it) as a new twist on Lamarckianism, an older theory of evolution. Jean-Baptiste Lamarck, a French naturalist and contemporary of Cuvier, had put forward what is often considered the first logical theory of evolution, arguing that the evolution of organisms, though complex, may be thought of as progressing up the chain of being. Some unknown force-Lamarck had difficulty in pointing to it-drove plant and animal life toward greater order and organization. Where he and Darwin differed was over this orderliness: Lamarck saw evolution in terms of teleological and orderly change, whereas Darwin conceived of it as a randomized process, one in which hazard played a part and fitness for one's environment determined survival.

As Reynolds notes in Walt Whitman's America, Whitman does not seem to have been especially perturbed by Darwin's new theory. If anything, the poet drew from Lamarckianism and Darwinism as they suited him. He was, it should be noted, an early and vocal proponent of the Darwinian view of evolution.$^{68}$ By 1886, in an interview with the Chicago Tribune, he could state flatly that "I believe in the doctrine of Darwin - in evolution from A to Z." ${ }^{69}$ Even so, this belief does not preclude his Lamarckianism, which, as Reynolds writes, optimistically "suggested that humans were not simply slaves of blind mechanical forces but could control their destiny" (246). Whitman adapts (or perhaps misunderstands) Darwinism in precisely this way, even in the same Tribune interview: "Everything is progressing toward that end as it should. The movements of our time in politics, science, religion, and sociology are toward a loftier conception of the human thought and constant upward tendency. I am content with the grand, sweeping advance, stamping an optimism on the age." ${ }^{70}$ Whitman's 
concern is not with change, per se, but control. He never denies Darwinism, which fits rather neatly into his poetic project, but instead syncretically restores to it a sense of directionality. This DarwinianLamarckian dialectic is strongly reflected in the language of eugenics found in "Manly Health and Training," especially in its ninth installment. Whitman's Lamarckian injunctions to self-improvement hinge on the idea of individual fitness, yet they also mirror the racial survival narratives that would spring up in response to Darwinism.

I intend the word "racial" here to mean whatever Whitman intends it to mean in "Manly Health and Training," though what that is is hardly clear. Even under the cover of a pseudonym, Whitman mostly avoids specifying. His generalities, like the "American race" or the "future race of men," are consistent with similar phrases typical of his poetry of the period. Many such phrases make their first appearance in the 1860 edition of Leaves of Grass, most of them future-oriented: "A new race, dominating previous ones, and grander far" ("Proto-Leaf"); "O race of the future!" (Chants Democratic, "Apostroph"); "Race of races, and bards to corroborate!" (Chants Democratic, Section 1); "I will make the most splendid race the sun ever yet shone upon" ( $A$ Boston Ballad, Section 5); and so on. In verse, these phrases tend to be loosely synonymous with an all-encompassing nationality, something like the Crèvecoeurian "individuals of all nations . . . melted into a new race of men." ${ }^{\prime 11}$ To this interpretation, Whitman's often sensitive poetic treatments of African-Americans and Native Americans lend some plausibility, though not a great deal. ${ }^{72}$ Indeed, in much of his prose, particularly in "Manly Health and Training," Whitman implies or even outright specifies that the "American race," both current and future, should be defined as white, or "Teutonic." In discussing the advantages of a colder climate, for example, Whitman posits a common eugenicist rationalization of the period, that "the most rugged and unfavorable climates turn out the noblest specimens of men," his examples being Scandinavians, northern Europeans, Germans, and "our Teutonic ancestors." 73 The African climate evidently does not rate as "unfavorable." Whitman's interest in eugenics has been studied quite thoroughly in the past fifty years or so, typically as it relates to his ongoing appetite for the pseudosciences in general, and 
phrenology in particular. ${ }^{74}$ "Manly Health and Training" will almost certainly provide more food for thought. As he does in Democratic Vistas (1870), in this newly uncovered series Whitman puts forth what Harold Aspiz has called "a sexual-eugenic program for an America whose youth lacked the 'magnetism of sex,' were 'puny, impudent, foppish, prematurely ripe, and characterized by an abnormal libidinousness." "75 Whitman's program in "Manly Health and Training," however, is much more explicit. He suggests that the health of a nation depends, in a Hobbesian sort of way, on the health of its individuals. Thus, Americans (or rather, American men) must train themselves to improve their physical and sexual prowess, so that America-asgrand-racial-experiment, that "race of races," will not die out. It is every bit as Darwinian as it sounds. Adversity, it seems, promotes strength and superiority, an idea that leads Whitman to some surprising social conclusions - for example, that poverty has its advantages for the nation:

[I]n the low-life shanties, and in all places, both city and country, where the lowest order of the population reside[, i]n utter defiance of all the laws of physiology, we see it arise, from the denizens of those places, some of the most splendid specimens of health and physical beauty in the world. . . This fact, which is so startling at first, and seems to knock spots out of all our calculations and advice, will, when further investigated, be found to come under the simple and true theory of health, and confirm it just the same as the rest. The children of a poor family, especially in the country, and to a great extent in cities also, are never injured by those pampering luxuries and condiments that are frequently the bane of the offspring of the rich-who are often literally killed by kindness. The former, if weak and puny, are perhaps more apt to die off, leaving only the hardier shoots to buffet the storms and exposures of life. ${ }^{76}$

Whitman's usual preference for strong, working-class "roughs" is evident here, but so is an atypically untempered strain of social Darwinism, to which he adds rhetorical emphasis by upending typical class assumptions about success. It should be noted that Whitman does not literally advocate the spread of poverty, but of animal power. Elsewhere in the "Manly Health" series he chastises the literate middle- and upper-classes for lacking such power, for their "half-way and unwholesomely developed mentality of modern times, as seen in 
large classes of people, literary persons," especially "these swarms of 'intellectual people" whom Whitman describes as being all brain, no brawn. If "the mentality of that subject was in a vitiated condition, . . . there was not enough brute animal in the man." 77 The nation, as Whitman embodies it, is short on muscle, physiologically and (by extension) politically.

It may be for this reason that Whitman uses the eighth installment of the "Manly Health" series to advocate for prizefighting, as well as for a fighting culture in general. In it, Whitman insists that he "believe[s] in the necessity of those means that help to develope [sic] a hardy, robust and combative nation . . . We do not think that community able to take care of its rights, and defend them successfully against all odds, where there exist only peaceful, pious, respectable and orthodox citizens. There must be something more." That "something more" is "a race of men who could and would fight, not by rote merely, but for the love of fight." ${ }^{\text {"78 }}$ As an instance of what he means, Whitman celebrates a recent bare-knuckle match between boxers John Morrissey (the reigning champion and a Tammany Hall man) and John C. Heenan. Whitman did not actually attend the match, which took place in Ontario, bare-knuckle boxing being outlawed in the United States at the time. In this installment of the "Manly Health" series, Whitman pushes rather passionately for its reinstatement. Arguing that "even Rome itself, in time, ... fell a prey to outside invaders far inferior to itself," he suggests that

in robust training for this life, which is itself a continual fight with some form or adversary or other, the aim should be to form that solid and adamantine fibre which will endure long and serious attacks upon it, and come out unharmed from them, rather than the ability to perform sudden and brilliant feats, which often exhaust the powers in show, without doing any substantial good. ${ }^{79}$

His exemplum is Morrissey, who evidently endured horrendous punishment in the eleven-round fight - a "rapid twenty-two minutes," Whitman calls it - before knocking out Heenan. As Whitman writes in "Poems of Joy" (1867), the fighter is "strong-brawn'd . . . , towering in the arena, in perfect condition, conscious of power, thirsting to meet his opponent." But he is also gentlemanly, as Morrissey is said 
to have been, sometimes pulling his final punch to help an opponent over to his corner. He is a hero, and once again, Whitman is drawn to the "brute" or "animal" aspect of his strength:

Just in the way as the institution of the horse-race, and nothing less than that, brings the breed of the horse up to a far, very far, higher pitch of physical perfection than could be attained by any other means known or possible upon earth - just exactly in the same way, . . . it remains to be distinctly confessed that nothing short of these fierce manly contests, in ancient and modern times, has led to the mightiest and most perfect development of the masculine frame, and proved what are the real rules consonant with its soundest physiology. Therefore, in opposition to the views expressed by the editors of the American newspapers, (the Atlas, we believe, among the rest,) we say a stern word or two, not in defence of these fights only, but in deliberate advocacy of them. ${ }^{80}$

In retrospect, Whitman's eventual service as a nurse during the Civil War, and his disillusionment with bloodshed, make this section rather shocking. His statements apparently upset contemporary readers, too. Among Whitman's unpublished manuscripts, editor Edward F. Grier catalogs what appears to be the beginning of a rebuttal, probably to a letter to an editor, in which Whitman reiterates that "the moral of the late fight" is that "endurance is the main thing-not a splurge at first" (NUPM 6:2259). Recycling his equine simile, he ventures that "there will be in America as great specimens of men, as fine horses, . . . as in any other part of the world" (NUPM 6:2259). This short, cancelled manuscript suggests that there was at least one printed response, in the Atlas or elsewhere, to Whitman's views on prizefighting. However, I have been unable to locate any, nor can I determine whether Whitman ever completed or published his rebuttal. Whatever he thought to say, it is clear that he did not feel like compromising on the subject of American bellicosity. The poet does warn vaguely against the initial "splurge" - that is, the desire to attack immediately and unthinkingly, later portrayed in the poem "Drum-Taps" as the naive excitement of Manhattanites (himself included) cheerfully preparing for war's "red business." 81 Whitman also notes that "the actual necessity of this kind of training, for fighting purposes, will never be the rule, but only the exception," but he maintains that "nothing short of a prize-fight will ever bring the rules of manly health and training to that systematic 
perfection which they are attaining, and out of which we, among the rest, have been able to write these articles for popular use." ${ }^{82}$ Overall, the prize-fighter acts as a metonym for the entire nation, making Whitman's concerns political, nationalistic, even expansionist. There is a prize to be fought for, and for Whitman that prize seems to be the frontier, or anyway the colossal size and strength its annexation confers upon America:

The nation is passing through several important physiological processes and combinations. To a great degree, it is yet getting acclimated-especially in the West, and on the Pacific coast, which latter is destined to have a huge influence on the future physique of America. ... Here the air is dry and antiseptic-everything grows to a size, strength and expanse, unknown in the Northern and Eastern States. Nature is on a large scale; and here, in time to come, will be found a wonderful race of men. ${ }^{83}$

Whitman's specification of the "Northern and Eastern States," and his recourse to thoughts of "race[s] of men," suggest that he may also have in mind an impending interstate conflict. At the moment of his writing in the Atlas, the Civil War was a mere two and a half years away. Political and racial tensions, as well as the threat of Southern secession, almost certainly undergird his concerns about outlasting a long and bloody conflict. For Whitman, a threat to democracy is by definition a bodily threat. Of Whitman's equation of politics and physiology, M. Jimmie Killingsworth notes that "democracy begins with the body, which is the link with nature and the common denominator among all classes, races, divided groups." ${ }^{84}$ Thus, the truest threats to democracy are those that, like prostitution or slavery, ignore "the value of an excellent body," as Killingsworth puts it, "the product of eons of evolution." ${ }^{\circ 5}$ Here, perhaps, is the "Manly Health" series' deepest concern. American democracy may be the endpoint of a Lamarckian evolution, or the incidental flower of a Darwinian world, but either way its fitness is shortly to be tested, even threatened with extinction. The men of the northeastern states must be strengthened not merely for their own happiness, but so that they might endure those "indescribably strong and bloody attacks, blows, and bruises" that are to come in the fight for national unity. ${ }^{86}$ The "lesson" of such a fight, 
Whitman concludes, is that "he wins who can 'best stand grief"'-a lesson the poet would soon learn all too well.

Of "Manly Health and Training," there is much more to be said. One might write a great deal, for example, on Whitman's treatment of masculinity in the text, or about homoeroticism and narratorial gaze in his descriptions of manly physique. I have barely scratched the surface of the text's investment in social reform, nor is there room here to discuss Whitman's engagement with water cures, vegetarianism, dietetics, gymnastics, or personal magnetism. And of course there is the matter of his conspicuous silence (rhetorical or otherwise) on the subject of womanhood. Such conversations are bound to spring up around such an invaluable, revealing, and even frustrating document. I will only add that the recovery of Whitman's life's work is far from over. It is probable that many more lost documents are out there, whether published or in manuscript form, in digital archives or dusty trunks. Whitman's work for the Long Island Patriot and Long Island Star, for example, written in the early to mid-1830s, is largely absent, nor has any original copy of the Long Islander under his editorship (1838-1839) turned up. The extent of his work in the New Mirror (1844) is still largely undocumented. Though he wrote for several months in the Brooklyn Freeman (1848-1849), only the first issue is still extant, the rest apparently having burned in an office fire. Any additional work he may have published in the New York Atlas, in 1858 or otherwise, is for now unknown. And that is only his journalism! Researchers still regularly turn up previously undocumented poems, interviews, letters, marginalia, and reprintings. Whole manuscripts or notebooks might even turn up somewhere, the ultimate example being four priceless early notebooks that, after disappearing in 1944, reappeared in 1995. Six further notebooks have yet to resurface. ${ }^{87}$ As with "Manly Health and Training," we may find that they were right under our boot-soles. 


\section{NOTES}

I would like to thank the American Antiquarian Society for its unwavering consideration and generosity - and the Penn State Library for parting, briefly, with one of the few loanable microfilm copies of the New York Atlas still in existence. Special thanks are reserved for image librarian Jaclyn Penny, whose kindness is matched only by her attention to detail. I also owe great debts to Ed Folsom, Kenneth Price, Jason Stacy, and Stefan Schöberlein, for their assistance, encouragement, and excitement. Without the help of these scholars and the AAS, the world would not have "Manly Health and Training."

1 Horace Traubel, With Walt Whitman in Camden, vol. 1 (Boston: Small, Maynard and Co., 1906), 164. Available on the Walt Whitman Archive (www.whitmanarchive. org).

2 Walt Whitman, Prose Works 1892, Volume II: Collect and Other Prose, ed. Floyd Stovall (New York: New York University Press, 1964), 360.

3 For the source of Whitman's words, see the final stanza of the first "Leaves of Grass" section (later retitled "Song of Myself") in Leaves of Grass (Brooklyn: 1855), 56. Available on the Walt Whitman Archive.

4 See Whitman's New York Dissected, by Walt Whitman: A Sheaf of Recently Discovered Nerwspaper Articles by the Author of Leaves of Grass, ed. Emory Holloway and Ralph Adimari (New York: R. R. Wilson, 1936).

5 See Silver's "Whitman in 1850: Three Uncollected Articles," American Literature 19 (1948): 301-317.

6 Joseph J. Rubin, The Historic Whitman (University Park: Pennsylvania State University Press, 1973), 311-354.

7 An even larger and more comprehensive list of Whitman "finds" could be made by including the many other recoveries of poetry, fiction, and manuscripts, made over the past century or so. Examples include the "Live Oak with Moss" manuscript discovered by Fredson Bowers (1955); two early published stories, "The Madman" and "Reuben's Last Wish," relocated by Emory Holloway (1956); "Tale of a Shirt" and "The Fireman's Dream," an early poem and short story, both found by Herbert Bergman (1982); and "A Sketch," another early poem recovered by Jerome Loving (1993). One might also count the four early Whitman notebooks that vanished in 1944 during transport from the Library of Congress, only to resurface fifty years later (see Alice Birney, "Missing Whitman Notebooks Returned to Library of Congress." Walt Whitman Quarterly Review 12 (Spring 1995), 217-229). And then there is William Swinton's Rambles Among Words (1859), a book of spirited and unrigorous etymology, much of it ghostwritten by Whitman, as C. Carroll Hollis demonstrated precisely one hundred years after the fact. For a thorough exploration of the topic, see Hollis's "Walt Whitman and William Swinton: A Co-operative Friendship," in American Literature 30 (1959), 425-449; and James Perrin Warren's "Whitman as Ghostwriter: The Case of Rambles Among Words" in WWQR 2 (Fall 1984), 22-30. 
8 Whitman's status as employee-writer, and his employer's continual scrutiny of his work, surely have something to do with this. As Karen Karbiener has recently noted of Whitman's stint with the Brooklyn Daily Times, the "domineering presence" of a newspaper proprietor probably led to some very uncharacteristic editorials on Whitman's part, not to mention the misattribution of other writers' work to Whitman. For Karbiener's quote, see her "Reconstructing Whitman's Desk at the Brooklyn Daily Times," in WWQR 33 (2015), 23.

9 Quote taken from Whitman's preface to Leaves of Grass (Brooklyn: 1855), iii. Available on the Walt Whitman Archive.

10 See Emerson's letter to Whitman in praise of Leaves of Grass, published without Emerson's consent at the end of the 1856 edition (Brooklyn: Fowler \& Wells, 1856), 345. Available on the Walt Whitman Archive.

11 M. Jimmie Killingsworth has debated whether to call this sort of freelance writing, of which the poet did a good deal in the 1850s and early 1860s, "literary journalism or prose non-fiction." See Killingsworth's entry on "Journalism, Whitman's" in The Routledge Encyclopedia of Walt Whitman, ed. J. R. LeMaster and Donald D. Kummings (New York: Routledge, 2011), 335. Available on the Walt Whitman Archive.

12 For those interested, the entire series will also be available at the Walt Whitman Archive eventually, complete with all original page images.

13 Probably the most thorough analysis of Whitman's evolution of personae is Jason Stacy's Walt Whitman's Multitudes: Labor Reform and Persona in Whitman's fournalism and the First Leaves of Grass, 1840-1855 (New York: Peter Lang, 2008). Stacy divides Whitman's public image into three distinct personae: the Artisan/Schoolmaster, the Editor, and finally the Bard.

14 In Specimen Days, his episodic autobiography, Whitman skips the year entirely, jumping from his 1856-1857 work on Leaves of Grass to the beginning of the American Civil War in 1861.

15 Whitman is thought to have begun working at the Daily Times in May 1857, though Karen Karbiener argues that he may have worked there as early as April 1856. For her rationale, see Karbiener's "Reconstructing Whitman's Desk,” 21-50.

16 The instance of "perfect health" I am thinking of comes from "Song of Myself" (1860): "I, now thirty-six years old, in perfect health, begin, / Hoping to cease not till death." See Leaves of Grass (Boston: Thayer and Eldridge, 1860-61), 8. Available on the Walt Whitman Archive. For Reynold's discussion of Whitman's health in 1858, see his Walt Whitman's America: A Cultural Biography (New York: Vintage Books, 1996), 375.

17 See "Live Oak with Moss," section 11. For readers who are unconvinced that "Live Oak" is autobiographical, see Alan Helms's discussion in his introduction to the poem, available on the Walt Whitman Archive, reproduced from The Continuing 
Presence of Walt Whitman: The Life After the Life, ed. Robert K. Martin (Iowa City: University of Iowa Press, 1992), 185-205.

18 In hisEmerson, Whitman, and the American Muse (Chapel Hill: University of North Carolina Press, 1982), 161-171, Jerome Loving makes this same case, that Whitman's "slough" of 1858-1859 occurs not coincidentally around his brother's marriage in early 1859. Loving later adds, in Walt Whitman: The Song of Himself (Berkeley: University of California Press, 2000), that Whitman's depression was "probably episodic" (234).

19 See "Walt Whitman," an extensive introductory biography of the poet, available on the Walt Whitman Archive. For what it's worth, Pfaff's does not sound like it always offered the most pleasant dining experience. Just a few years afterward, in a letter to Whitman, friend and New York Times editor John Swinton recalled the experience of Pfaff's as one of having to "sit by [the] privy and eat sweet-breads and drink coffee, and listen to the intolerable wit of the crack-brains." Even so, Whitman seems to have enjoyed himself. For the most thorough account of Pfaff's place in early American bohemia, see Stephanie Blalock's "Go to Pfaff's!": The History of a Restaurant and Lager Beer Saloon (Bethlehem, PA: Lehigh University Press, 2014).

20 [Anonymous]. "Leaves of Grass.” Long-Islander 3 (December 10, 1858): 2. Available on the Walt Whitman Archive.

21 This passage first appeared in the Atlantic Monthly (April 1860), pages 445-447, under the title "Bardic Symbols." Soon thereafter, Whitman enfolded it into Leaves of Grass (1860), 197.

22 Christine Stansell, "Whitman at Pfaff's: Commercial Culture, Literary Life and New York Bohemia at Mid-Century," WWQR 10 (Winter 1993), 107.

23 See the Walt Whitman Archive's Portraits Gallery for this photograph (image 007), plus Whitman's reflections on it in 1889. The poet could not later recall when and where it had been taken, and was greatly fascinated by what he began calling the "mysterious photograph" (Traubel, $W W W C, 4: 393$ ).

24 Traubel 4:159.

25 See Whitman's Correspondence, 6 vols., ed. Edwin Haviland Miller (New York: New York University Press, 1961-1984), 1:45. It should be noted that none of Whitman's 1858 correspondence survives, not even a scrap.

26 See Whitman's Notebooks and Unpublished Prose Manuscripts, 6 vols., ed. Edward F. Grier (New York: New York University Press, 1984), 6:2233-2234; hereafter abbreviated as NUPM.

27 Matthiessen connects Whitman's poetry to oratory in The American Renaissance (New York: Oxford University Press, 1968), 549-58.

28 For one of Whitman's earliest encounters with the opera and vocal per-formance, see his trio of letters to the editor of the Washington, DC, National Era, most recently republished in Rollo G. Silver's "Whitman in 1850: Three 
Uncollected Articles," American Literature 19 (1948), 301-317. "Restrain gesture" comes from NUPM 6:2231.

29 William L. Finkel, "Sources of Walt Whitman's Manuscript Notes on Physique," American Literature 22 (1950), 308; see also Thomas B. Harned, "Walt Whitman and Physique," in The Complete Writings of Walt Whitman, ed. Richard M. Bucke, Thomas B. Harned, and Horace L. Traubel (New York, 1902), 8:261-274.

30 For Grier's editorial notes on the draft advertisements, see NUPM 6:2255. Barney's thoughts on the drafts appear in A Companion to Walt Whitman, ed. Donald D. Kummings (Malden, MA: Blackwell, 2009), 237, in his article, "Nineteenth-Century Popular Culture."

31 Besides being advertised in the Atlas, the series was briefly teased in the Tribune and Times. See the New-York Daily Tribune (September 11, 1858), 1; and Nerw-York Times (September 11, 1858), 5. See image on Table of Contents page.

32 According to William White, others include "Paumanok," "A Traveller," "A Pedestrian," "A Schoolmaster," "You Know Who," "George Selwyn," and "J. R. S." See White's "Walt Whitman's Pseudonyms," American Notes and Queries 4 (March 1966), 105.

33 See "The Habitants of Hotels" (March 10, 1848) in Emory Holloway's The Uncollected Poetry and Prose of Walt Whitman, 2 vols. (Garden City, NY: Toronto, Doubleday, Page and Company, 1921), 193-195. Whitman created the pseudonym by joining a common "Bowery b'hoy" name (Mose) to his mother's maiden name (Van Velsor).

34 See Finkel, "Sources," 308-331.

35 Finkel, "Sources," 330. Here, he quotes one of Whitman's fragments on health and physique; see NUPM 6:2249.

36 For his and Maurice Bucke's final accounting of these early influences, see "A Backward Glance O'er Travel'd Roads" in Leaves of Grass (Philadelphia: David McKay, 1891-92), 432-433. Available on the Walt Whitman Archive. Careful readers, like Emerson, could sense them. So could those who remembered Whitman's earlier, more derivative writings. In the New York Sun, in March 1876, Richard Henry Dana, Jr., notes of Whitman's early fiction that "there was no flavor of the soil whatever about them. They might just as well have been written in London as here, for all that they expressed of the genius of our civilization. Thus we see that Walter Whitman did not leap from the fresh-turned furrow to Olympian heights. . . . He seems, indeed, to have taken up his rude measures and gnarled and knotted lines as an afterthought; and it has proved a successful venture.”

37 Price explores Whitman's late-life "concessions to literary fashion" in "Crisis and Control in the Late Phase," the fourth chapter of his Whitman and Tra- 
dition:The Poet in His Century (New Haven:Yale University Press, 1990). Price's quote appears on page 70 .

38 For a good primer on the subject, see David Goodale's early article on "Some of Walt Whitman's Borrowings," in American Literature 10 (1938), 202213. A more in-depth case study may be found in John Engell's "Walt and Sir Walter or the Bard and the Bart: Balladeers," WWQR 5 (Spring 1988), 1-15, which traces Whitman's connection to Walter Scott. I will note that Whitman was not insensitive to the role plagiarism has always played in great poetry. Of Horace Traubel he once asked: "Do you ever think, Horace, what infernal plagiarists the big fellows are- big lawyers, big preachers, big writers-even Shakespeare, Longfellow: how much they borrow and never pay back?" See Traubel 2:472. Available on the WaltWhitman Archive. Other important studies of Whitman's borrowings include Ted Genoways's "Civil War Poems in 'Drum-Taps' and 'Memories of President Lincoln,"' in A Companion to Walt Whitman, ed. Donald D. Kummings (Malden, MA: Blackwell, 2009), 522-538; and Stefan Schöberlein's “'The Ever-Changing Nature of the Sea': Whitman's Absorption of Maximilian Schele de Vere," WWQR 30 (2013), 57-77.

39 See his entry on "Leaves of Grass, 1860 edition" in The Routledge Encyclopedia of Walt Whitman, 362. Available on the Walt Whitman Archive.

40 "Leaves of Grass, 1856 edition," The Routledge Encyclopedia of Walt Whitman, 359. Available on the Walt Whitman Archive.

41 For more on Whitman's woes in 1857 and his work for the Daily Times, see Dennis K. Renner's entry on the "Brooklyn Daily Times" in Walt Whitman: An Encyclopedia, 81-82.

42 See Frederic Hudson's Fournalism in the United States, from 1690 to 1872 (New York: Harper and Brothers, 1873), 338.

43 See Alfred McClung Lee's The Daily Newspaper in America, 2 vols. (New York: Routledge, 2000), 1:190. Basic bibliographic information about the Atlas comes from Chronicling America, the Library of Congress's Historic American Newspapers database. See "About Sunday Morning Atlas. (New York) 1838-1840" and "About The New-York Atlas. (New York) 1853-1881," (chroniclingamerica.loc.gov).

44 See Jeff's letter to their mother, Louisa Van Velsor, dated April 23-24, 1848: "We get the Eagle and Brooklyn Star quite often, and also the New York, [:] Tribune, Mirror, Globe, Dispatch, Sunday Times, Atlas, \&c, \&c." Available on the Walt Whitman Archive.

45 See Loving, Walt Whitman, 57. 
46 Taken from the New York Aurora (February 1, 1842), 1. Available on the Walt Whitman Archive.

47 David S. Reynolds, Walt Whitman's America: A Cultural Biography (New York: Vintage Books, 1995), 101.

48 In Conserving Walt Whitman's Fame: Selections from Horace Traubel's Conservator, 1890-1919, ed. Gary Schmidgall (Iowa City: University of Iowa Press, 2006), 82.

49 [Anson Herrick,] "Walt Whitman," in The New York Atlas (July 1, 1860), editorial page, col. 5 .

50 [Herrick,] "Walt Whitman," col. 5.

51 Rubin, Historic Whitman, 84. Herrick would later visit Whitman in a Washington, D.C., hospital ward in 1864, though it is not documented what the editor, by then a U.S. Representative, said to the poet. In a letter Whitman wrote to his mother, June 3, 1864, he reports that "Mr Kalbfleisch [a U.S. Representative and former New York City Mayor] \& Anson Herrick, (M C from New York) came in one of the wards where I was sitting writing a letter this morning, in the midst of the wounded-Kalbfleisch was so much affected by the sight that he burst into tears." See The Correspondence, 1:229-230. These are the last words Whitman ever wrote about Herrick.

52 Untitled editorial, Brooklyn Daily Times (October 20, 1858), 2.

53 Untitled editorial, Brooklyn Daily Times (October 20, 1858), 2.

54 Untitled editorial, New York Aurora (March 28, 1842), 2. Available on the Walt Whitman Archive.

55 See Karbiener, 21-50. "Manly Health and Training" may have been written in his office at the Daily Times; some of Whitman's notes for the series are jotted on the backs of the same blue "City of Williamsburgh" tax forms used for so many of his manuscripts of the period.

56 “Alas! Poor 'Saturday Press' [from the Sunday Atlas]," New-York Saturday Press (November 17, 1860): 1. Quoted in Leif Eckstrom, "On Puffing: The Saturday Press and the Circulation of Symbolic Capital," in Whitman Among the Bohemians, ed. Joanna Levin and Edward Whitley (Iowa City: University of Iowa Press, 2013), 55.

57 See Walter Whitman, "Reuben's Last Wish," New York Washingtonian (May 21, 1842), 1-2; and "The Madman," New York Washingtonian and Organ (January 28, 1843), 1. "The Madman" is officially the first chapter and a half of an unfinished novel. Since no additional chapters have turned up, it is generally presumed that Whitman gave it up, or that the editors of the Washingtonian decided to drop it. For the complete text of "The Madman," see Franklin Evans; or The Inebriate. A Tale of the Times, ed. Chris 
Castiglia and Glenn Hendler (Durham: Duke University Press, 2007), 117-122. For a brief account of the rediscovery of "The Madman" and "Reuben's Last Wish," see Emory Holloway's "More Temperance Tales by Whitman," American Literature 27 (1956), 577-578.

58 Loving, WaltWhitman, 57.

59 "Manly Health and Training, with Off-Hand Hints Toward Their Conditions," New York Atlas (November 28, 1858), 2.

60 "Manly Health and Training," Atlas (December 19, 1858), 6.

61 Notes and Fragments Left by Walt Whitman, ed. Richard Maurice Bucke, in The Complete Prose Works of Walt Whitman, 6 vols. (New York: G.P. Putnam's Sons, 1902), 6:12.

62 Leaves of Grass (Brooklyn: 1855), ix.

63 "Manly Health and Training," Atlas (September 12, 1858), 1.

64 Leaves of Grass (Brooklyn: 1855), 55. Available on the Walt Whitman Archive. This poem appears, with modified punctuation, in all subsequent editions.

65 The term "scientist" did not even exist until 1833, when it was coined by English historian of science William Whewell.

66 Cuvier's findings in translation, along with a thorough editorial introduction, may be found in Martin J. S. Rudwick, Georges Cuvier, Fossil Bones, and Geological Catastrophes: New Translations and Interpretations of the Primary Texts (Chicago: University of Chicago Press, 1998).

67 Even less popular was Malthus's suggestion that family size be limited by law.

68 Reynolds, 246. Much has been written on Whitman's engagement with Lamarck and Darwin. For a brief introduction, see James T. F. Tanner's entry on "Evolution" in The Routledge Encyclopedia of Walt Whitman, 215-216. More in-depth discussions may be found in Joseph Beaver's WaltWhitman: Poet of Science (New York: King's Crown, 1951); James T. F. Tanner's “The Lamarckian Theory of Progress in Leaves of Grass," in the Walt Whitman Review 9 (1963), 85-100; David Charles Leonard's "Lamarckian Evolution in Whitman's 'Song of Myself," in the Walt Whitman Review 24 (1978), 21-28; Harold Aspiz's Walt Whitman and the Body Beautiful (Urbana: University of Illinois Press, 1980); and Hertha D. Wong's “This Old Theory Broach'd Anew': Darwinism and Whitman's Poetic Program," in WWQR 5 (Spring 1988), 27-39.

69 W.H.B., "Talks with Noted Men," Chicago Daily Tribune (June 12, 1886), 10. Available on the Walt Whitman Archive.

70 W.H.B., "Talks with Noted Men," 10. 
71 J. Hector St. John de Crèvecoeur, Letters from an American Farmer, ed. Susan Manning (New York: Oxford University Press, 1998), 44.

72 See, for example, the "runaway slave" passage in section 1 of Leaves of Grass (1855), later to be made section 10 of "Song of Myself"; or his disgust at "The Slave Trade," found in the third installment of his Life Illustrated series (1856).

73 "Manly Health and Training," Atlas (November 7, 1858), 1.

74 See especially Aspiz's Walt Whitman and the Body Beautiful, and Killingsworth's Whitman's Poetry of the Body (Chapel Hill: University of North Carolina Press, 1989).

75 Harold Aspiz, "Sexuality and the Pseudo-Sciences," in Pseudo-Science and Society in 19th-Century America, ed. ArthurWrobel (Lexington: University Press of Kentucky, 1987), 145. Aspiz quotes in turn from Democratic Vistas.

76 "Manly Health and Training," Atlas (September 12, 1858), 1.

77 "Manly Health and Training," Atlas (September 12, 1858), 1. Italics in original.

78 "Manly Health and Training," Atlas (October 31, 1858), 1. Italics in original.

79 "Manly Health and Training," Atlas (October 31, 1858), 1. Italics in original.

80 "Manly Health and Training," Atlas (October 31, 1858), 1. Italics in original.

81 The poem was later titled "First O Songs for a Prelude." See Drum-Taps and Sequel to Drum-Taps (New-York, 1865-66), 7. Available on the Walt Whitman Archive.

82 "Manly Health and Training," Atlas (October 31, 1858), 1.

83 "Manly Health and Training," Atlas (October 31, 1858), 2.

84 Whitman's Poetry, 8.

85 Whitman's Poetry, 8.

86 "Manly Health and Training," Atlas (October 31, 1858), 1.

87 See Birney, "Missing Whitman Notebooks," 217-229. 